\title{
RULE OF LAW AND DUE PROCESS: A COMPARATIVE VIEW OF THE UNITED STATES AND JAPAN
}

\author{
Noriho UrabE*
}

INTRODUCTION: RULE OF LAW AND RECHTSSTAAT

Although this author does not know whether the phrase "Rule of Law" is popular in the United States outside of jurisprudential discussions, it seems that in Japan the term "Rule of Law" (ho no shihai) is used less often than the word Rechtsstaat (hochi-koku or hochi kokka), or "state based on law" or "ruled by law." For instance, when a serious illegal activity or crime has been committed, a prosecutor or other concerned government official often states, "This kind of illegal activity is never permissible in the state ruled by law (hochi kokka)." The hochi kokka means something like a state that preserves the public peace or protects people from crime. This is far different from the Anglo-American concept of the Rule of Law. Therefore, when Japanese legal scholars discuss the Rule of Law, the first problem to be discussed is the difference between the Rule of Law and the Rechtsstaat, both of which have been imported into Japanese law despite their disparate origins in AngloAmerican and German law.

Since Albert Venn Dicey advanced it as the pride of the English Constitution in the nineteenth century, ${ }^{1}$ the modern Rule of Law has meant many things to many people. Therefore, it is difficult to define the meaning of the Rule of Law briefly and exactly. But we can say that the core of the Rule of Law, which has been supported consistently as a fundamental principle of the English and American Constitutions, is that governmental power be bound strictly by law in order to protect individual freedom or liberty. The law exists to protect individual rights and liberties both in substance and in procedure.

It goes without saying that such an understanding of the law is made possible by the existence of the common law, which is judge-made law. In the common law system, the law is enforced by courts, and the Rule of Law is realized through the judicial process. However, in England, where Parliament plays the leading role through the constitutional principle of the sovereignty of Parliament, there exists no law superior to the statutes adopted by the

\footnotetext{
Copyright $(\mathcal{O} 1990$ by Law and Contemporary Problems

* Professor, Faculty of Law, Kobe University.

1. A. Dicey, Introduction to the Study of the Law of the Constitution 188-205 (10th ed. 1959).
} 
Parliament. Therefore, the Rule of Law in England actually means that the administrative power is bound strictly by law and that the judiciary reviews the lawfulness of administrative action. On the other hand, in the United States, popular distrust of the legislature in colonial times and the years immediately following independence gave rise to a somewhat different notion of the Rule of Law. In the United States, both legislative and administrative actions are subject to the Rule of Law. Of course, both the Constitution as supreme law and the system of judicial review have arisen from this notion of the Rule of Law.

In contrast to the Anglo-American idea of the Rule of Law, which regards the law as protecting individual rights and liberties, the German idea of Rechtsstaat, established in the nineteenth century, is unconcerned with the content of the law. It means only that administrative action should be based on a law-"Administration by Law." Rechtsstaat assumes the superiority of the administrative power over the people and controls this superior administration through legislative statutes providing the grounds and framework of administration. The law applied to administration is distinguished from the ordinary law applicable to the people and is regarded as a special law peculiar to administration, or administrative law. Therefore, in the traditional Rechtsstaat, administrative action is not subject to the judicial review of the ordinary courts, whose task is to administer the ordinary law. Only the administrative court, which itself is considered an administrative organ, can review administrative actions. In this sense, despite a superficial resemblance to the English Rule of Law, with its emphasis on the notion of administration by law, the Rechtsstaat is very different. The Rechtsstaat, when combined with the legal positivism that regards the law as an order of the ruling authority, represents no more than the self-restraint of the state power. Indeed, the Rechtsstaat in nineteenth-century Germany was merely a concession of the monarch. ${ }^{2}$ The Rechtsstaat did not require that the law itself should protect individual rights and liberties. It was only the basis for administrative action. Insofar as the Rechtsstaat forbids arbitrary activity by the administrative power, it protects the individual's right to know what the law is and how it will be applied. But, unlike the Rule of Law, it is by no means a principle for protecting individual rights and liberties.

In summary, the major distinction between the Rule of Law underlying traditional Western constitutionalism and the Rechtsstaat or Rule by Law of German and Japanese origin is where power and rights are vested. The Western. Rule of Law holds that powers and rights vest naturally in individuals, and that government is limited in its power to infringe upon these rights. On the contrary, the Rechtsstaat, a more hierarchical tradition, holds that all powers and rights naturally vest in government, which then allocates rights and powers to its citizens. Rechtsstaat does not recognize any individual rights as fundamental; government and not nature is the source of individual

2. M. Kriele, Einfuerung in die StaAtslehre 168 (1975) (Japanese ed., M. Shiyake trans. 1989). 
rights. This distinction is generally discussed in the Japanese academic world of jurisprudence. ${ }^{3}$ This is because the Meiji Constitution of 1889 surely stood on the German concept of the Rechtsstaat.

\title{
II
}

\section{Rule of LaW and the Constitution}

\begin{abstract}
A. The Rechtsstaat in the Meiji Constitution and the Rule of Law in the Constitution of Japan
\end{abstract}

The Meiji Constitution was modeled after the Prussian Constitution and introduced the German Rechtsstaat principle. The guarantee of the "rights of the subject" in the Meiji Constitution was limited by a provision securing these rights only "according to law," and therefore any kind of restriction on the "rights of the subject" was allowed so long as it had a statutory basis. In short, the Meiji Constitution required only that administration be based on statute, but it imposed no limitation on the contents of the statutes.

Furthermore, the whole governing power under the Meiji Constitution belonged to the emperor. The Parliament was not the representative organ of the people but an organ supporting the legislative power of the emperor. All law was regarded as an order of the emperor. Therefore, the emperor was able to issue an order without the participation of the Parliament in certain situations. ${ }^{4}$ Thus, there existed an important exception even to the formal administration by law, or Rechtsstaat, principle.

The central meaning of the Rechtsstaat in the Meiji Constitution was that the people should obey the orders of the emperor. It was Rule by Law, which was far from the Rule of Law. And, as a matter of course, judicial control of administrative and legislative action was denied. The legality of administrative action was only reviewed by the administrative court, which was regarded as an administrative organ. But even the administrative court's review of administrative action was limited to certain matters defined by statute. Rechtsstaat in the Meiji Constitution was by no means for the purpose of protecting people's rights and liberties. ${ }^{5}$ That is because the Constitution itself was given by the emperor to the people and asked the people to assume the "duty of allegiance." The Imperial Rescript for the Promulgation of the Constitution of 1889 said as follows: "My Ministries should be responsible for putting this Constitution in operation on my behalf, and my present and future subjects should assume the duty of eternal allegiance to this Constitution."

On the other hand, the fundamental principle underlying the 1947 Constitution is that the Constitution was established by the Japanese people, ${ }^{6}$

3. Tsuji, Hochi Gyosei to Ho no Shihai, 337 Shisō 626, 627-31 (1952); Ukai, Ho no Shihai, in KenPō Ni OKeru Shocho to Dainyo 216-20 (N. Ukai ed. 1977).

4. Meji Const. art. 9.

5. Takayanagi, Nihon ni okeru Ho no Shihai, 12 Shakai Kagaku KenkyU 33, 33-36 (1961).

6. 1947 Const. preamble. 
and the National Diet, the representative organ of the people, monopolizes the legislative power. ${ }^{7}$ Therefore, in principle, both the Constitution and the law are the manifestations of the will of the people instead of the order of the ruling authority. In this way, the Constitution has established the notion of binding the governmental power by the will of the people. The Constitution also established the concept of fundamental human rights, together with the system of judicial review for assuring the protection of these rights. These characteristics have led to a general view in Japanese jurisprudence that the basic principle of the 1947 Constitution is the Rule of Law, as distinguished from the Rechtsstaat of the Meiji Constitution. ${ }^{8}$

\section{B. How is the Rule of Law Incorporated in the Constitution?}

Like the United States Constitution, the Constitution of Japan has no express provision for the Rule of Law. But it is understood to express the Rule of Law in the following ways. ${ }^{9}$ The first way is by the concept of the supreme law. Chapter 10 of the Constitution is titled "Supreme Law" and implies the Rule of Law. Article 98 provides that "no law, ordinance, imperial rescript or other act of government, or part thereof, contrary to the provisions hereof, shall have legal force or validity." This provision could be seen merely as a statement of a natural attribute of a "rigid constitution," 10 that is, that the Constitution is simply the highest level in a system of positive law. If so, the supreme law would embody the legal positivistic concept rather than be an expression of the Rule of Law. Indeed, the Meiji Constitution too was deemed the supreme law in this sense. However, as long as Article 98 is construed as stating that all governmental actions should be ruled by the Constitution, one could say that this provision alone reflects the idea of the supremacy of law or the Rule of Law. But Article 98 says nothing about the substantive contents of the law that is to be the rule. A similar provision would make any constitution the Rule of Law, whether it protected rights or not.

The Japanese Constitution goes further than this. The first Article of Chapter 10 confirms the perpetuity and inviolability of fundamental human rights. " This mears that fundamental human rights are the supreme law of Japan. Therefore, the concept of the supreme law in the Constitution is to be understood not only as a legal positivistic and formalistic concept but as a concept with the substantive content of protecting fundamental human rights. It is for this reason that the concept of the supreme law in the Constitution is deemed to be an expression of the Rule of Law. ${ }^{12}$

7. Id. art. 41 .

8. Ito, Ho no Shihai to Nihonkoku Kenpō, in KenPō Koza 133 (S. Kiyomiya \& I. Sato eds. 1963); Tsuji, supra note 3, at 631; Ukai, supra note 3, at 220.

9. Ito, supra note 8 , at $134-38$.

10. Here, I have used the phrase "rigid constitution" to mean a constitution that provides a more burdensome procedure for its amendment than merely passing a statute.

11. 1947 Const. art. 97.

12. N. Ashibe, Kenpō Kogi Noto 1, 31 (1986). 
The second way the Constitution incorporates the Rule of Law is by guaranteeing fundamental human rights under Chapter 3. If the protection of individual rights and liberties is the kernel of the Rule of Law, Chapter 3 of the Constitution, which guarantees people's rights unconditionally, must be regarded as a direct expression of the Rule of Law. Under the 1947 Constitution, even the National Diet, the representative organ of the people, cannot restrict the fundamental rights of the people. In other words, the fundamental rights of the people bind the legislative power. This represents the most important difference between the Meiji Constitution and the 1947 Constitution.

Requiring due process of law under Article 31 is the third way in which the Constitution incorporates the Rule of Law. The Rule of Law as an AngloAmerican constitutional principle has its roots in the Magna Carta of 1215, and the phrase "except by the law of the land" in the thirty-ninth clause of that instrument has been read as "without due process of law." The Rule of Law and due process have continued to be closely related in Anglo-American law. As for Article 31 of the Constitution, there are some arguments as to whether it has the same meaning as the due process clauses of the fifth and fourteenth amendments of the Constitution of the United States, because the due process clauses of the United States Constitution are concerned both with procedure and substance. But it is understood almost unanimously that Article 31 requires at least "procedural due process" in restricting the people's rights and liberties. From this point of view, Article 31 is also deemed to be an expression of the Rule of Law.

The fourth expression of the Rule of Law in the Constitution is that the whole judicial power is vested in the Supreme Court and lower courts under Article 76. Contrary to the Meiji Constitution, in which the judiciary could not handle administrative cases, the 1947 Constitution vests ordinary courts with jurisdiction over administrative cases and prohibits the establishment of any extraordinary court, such as an administrative court. Administrative action is subject to the judicial review of the ordinary courts, and the superiority of the judiciary over the administrative bureaucracy is a constitutional principle. Needless to say, this is an important element of the Anglo-American Rule of Law.

Finally, Article 81 of the Constitution establishes the system of judicial review. Although the Rule of Law in England does not include the system of judicial review of constitutionality of legislation, one can say that the Japanese system of judicial review is an expression of the American Rule of Law or stands on the principle of the American Rule of Law.

We can recognize the establishment of the principle of the Rule of Law in the Constitution in the above-mentioned points. But the problem is whether this constitutional principle is realized in practice. 


\section{III \\ Rule of Law and Due Process in Japan}

A. Some Arguments on the Rule of Law and Due Process in England and in the United States

The meaning of the Anglo-American constitutional principle of the Rule of Law has not remained the same from Dicey's time to today. Various aspects have changed, especially since the Great Depression of the 1930s, as government administration has come to exert significant influence on the nation's life. The government no longer confines itself primarily to the negative work of removing obstacles that hinder the activities of the people. It has taken a more active part in the nation's life by stabilizing the economy, realizing the general welfare, and so on. Such an expansion of administrative power necessarily results in the delegation of an ever-growing number of fields to administrative discretion. Today, we do not require administration only to carry out legal details but also to make substantive decisions. For this reason, the law can no longer bind administrative action strictly.

Dicey's concept of the Rule of Law denied any discretion to administration. As Dicey saw it, administration was required to follow law in its substantive decisions. But this concept has been unable to maintain its validity, at least in its original form. There have been criticisms of the Diceyan Rule of Law in England since the 1930s. For instance, in 1933, W. Ivor Jennings, who advocated the general welfare state, attacked the Diceyan Rule of Law, which supported the laissez faire economic system. ${ }^{13}$ He concluded that if the Rule of Law "means that the State exercises only the functions of carrying out external relations and maintaining order, it is not true. If it means that the State ought to exercise these functions only, it is a rule of policy for Whigs (if there are any left)." 14

In England today, on the premise that administrative discretion is inevitable, procedural rather than substantive protection is stressed as the essence of the Rule of Law, particularly in the fields of welfare administration, urban planning, and the like. ${ }^{15}$ If administrative discretion is inevitable, and the law is unable to bind strictly the substance of the final decision of administration, procedural protections, such as notice and hearing to an interested person, are absolutely necessary in order to secure the rights and liberties of the people. The focus of the Rule of Law seems to have been moving from substance to procedure in its homeland, England. It is said that the principles of "natural justice" have come to play a very important part in British administrative law "as a kind of equivalent to the constitutional right to due process." 16

13. Sir W. Jennings, The Law and the Constitution (1933).

14. Id. at 311 .

15. Jowell, The Rule of Law Today, in The Changing Constitution 8 (J. Jowell \& D. Oliver eds. 1985).

16. Wade, British Administrative Law and Natural Justice, 37 Коно Kenкyu 223 (1975). 
In the United States, "due process of law" is concerned with both procedure and substance. "Substantive due process" was the legal expression of a laissez faire economy. ${ }^{17}$ It is well known that the notion of substantive due process has been subjected to much criticism since the New Deal era, when the laissez faire economic system could no longer be maintained. Substantive due process is consistent with the Diceyan concept of the Rule of Law, which laid stress on the substance of the law and was also the legal expression of laissez faire and which has also been criticized in England since the 1930s. However, since the 1960s, the Supreme Court of the United States has again developed substantive due process, not to protect property rights, but to protect fundamental rights not mentioned specifically in the Constitution. ${ }^{18}$

Of course, we can find much to appreciate in these decisions, especially in the Warren Court's libertarian decisions, which expanded the protection of individual rights and liberties. ${ }^{19}$ On the other hand, there has been strong criticism of these decisions on the grounds that the Warren Court pursued exactly the same course as the "old court" by reading into the Constitution certain values beyond its text. ${ }^{20}$ Therefore, critics insist that one cannot admire the Warren Court while criticizing the old court. They say that judges are "not authorized to revise the Constitution in the interest of 'justice,' "'21 and that by doing so the Warren Court violated the Rule of Law. ${ }^{22}$ Another criticism is that " 'substantive due process' is a contradiction in terms." 23 By challenging the legitimacy of the Warren Court's decisions, these critics in effect sustain the argument that "judicial review alone cannot eliminate the possibility of a certain kind of governmental oppression-oppression by the judges themselves." 24

The protection of individual rights, due process of law, and judicial review are the core of the Rule of Law in America. The fact that there is controversy about these subjects suggests that in the United States, too, the Rule of Law means many things. Even so, one can find a consensus in England and the United States that the central meaning of the Rule of Law is that governmental power should be bound by the law. ${ }^{25}$ In Japan, things are quite different.

17. See, e.g., Lochner v. New York, 198 U.S. 45 (1905).

18. E.g., Roe v. Wade, 410 U.S. 113 (1973) (Supreme Court explicitly recognized that the "liberty" protected by the fourteenth amendment includes the "right to privacy"); Griswold v. Connecticut, 381 U.S. 479 (1965).

19. See, e.g., A. Cox, The Role of the Supreme Court in American Government 35-40 (1976); A. Cox, The Warren Court (1968).

20. R. Berger, Government by Judiciary $312-37$ (1977)

21. Id. at 289 .

22. Id. at 284-92.

23. J. Ely, Democracy and Distrust 18 (1980). Although he offers this criticism, Professor Ely is a defender of the legacy of the Warren Court. See id. at 55, 69-70, 73-75.

24. M. Tushnet, Red, White, and Blue 4 (1988).

25. See Scheiber, Public Rights and the Rule of Law in American Legal History, 72 CAlif. L. REv. 218 (1984). However, Professor Scheiber says that it is mistaken "to limit our understanding of rule of 
B. Some Arguments on the Rule of Law in Japan

In Japan, the meaning of the Rule of Law was extensively debated for a couple of years before and after 1960. The most enthusiastic advocates of what they called the Rule of Law in those years were the then Chief Justices of the Supreme Court, Kotaro Tanaka and Kisaburo Yokota. To them, the central meaning of the Rule of Law was that the people should obey the law. According to Tanaka, "Rule of Law" was the antithesis of "Rule of Force." He said that a state of disorder in postwar Japan had misled people into justifying the use of force.

It has started from the labor dispute, in which the use of force has been legalized within a strict limitation. Beyond this limitation, justification of the use of force has been widely extended to political movements or some other ways to secure one's own interest. This tendency has been growing greater and greater, and in an extreme case it takes the form of a mass movement, by which the normal functioning of the Diet or of the court is obstructed. ${ }^{26}$

Tanaka insisted that "it is the people in general who are subject to the Rule of Law, including both the individual person and private groups, and hence the most important thing is to exclude the use of private force, which invades the Rule of Law."'27

Yokota, who was Tanaka's successor as Chief Justice, spoke the same way but more clearly. He said that "the Rule of Law today means that the law rules the people, and that the people should obey the law and should act as the law ordains."28 Although Yokota admitted that this Rule of Law was somewhat different from the Anglo-American Rule of Law, in his opinion this difference was of little importance, because to him the Rule of Law meant the exclusion of unlawful force of any kind. Hence, whether this "force" was governmental power or private force was a matter of no importance. According to Yokota, the reason that the notion of the Rule of Law as a limit on governmental power had been established in England was that the autocratic government had potentially unbounded power in those days. But in 1962, he said, "there is no autocratic government at all," and so "it is hard to imagine that the government shall exercise an arbitrary power. [Therefore,] to make the law superior to governmental power . . . is not important. On the other hand, there are still many cases in which the people do not obey the law or do not act as the law ordains."29 Yokota further said that mass movements advocating certain political ideologies often exercised violent force, disregarding the law. Therefore, the most important purpose of the Rule of Law was not to bind governmental power but to exclude the use of force by the people and to require the people to obey the law. ${ }^{30}$

\footnotetext{
against government." Id. at 219.

26. Tanaka, Ho no Shihai to Shizen-ho, 193 Jurisuto 6, 11 (1960).

27. Id.

28. Yokota, Ho no Shihai to Saiban, 14 Hoso Jıнō 1, 7 (1962).

29. Id. at $10-12$.

30. Id. at 12-13.
}

law in our constitutional and legal history so as to confine it altogether to notions of private claims 
Tanaka and Yokota shared the perception that there existed a dangerous tendency in those days in Japan to resort to violence and to ignore the law. They found this tendency in contemporary labor movements and political mass movements, specifically in the huge mass movement against the revision of the U.S.-Japan Security Treaty from 1959 to 1960.

The understanding of the Rule of Law articulated by these two former Chief Justices shows that prewar Rechtsstaat thinking still remains strong in Japan. Furthermore, the fact that Tanaka and Yokota were not only Chief Justices of the Supreme Court but also prominent law professors who understood the Rule of Law in this way is enough to give an idea of the actualities of the Rule of Law in Japan. In practice, the Rule of Law in Japan does not work as a principle to protect the rights and liberties of the people. Rather, it is no more than an ideology to legitimize domination.

If the Rule of Law in Japan has such a meaning as Tanaka and Yokota asserted, it is natural that the Constitution, which is the direct expression of the supremacy of law over governmental power, plays no important role in Japanese society. Of course, I do not intend to say that the Constitution is treated entirely as a trivial instrument. On the contrary, I would say that the Constitution is given much importance in Japan as a matter of form or theory. ${ }^{31}$ For instance, in Japan, in order to acquire a school teacher's certificate, one must have credit for a university level course on the Constitution of Japan. Moreover, constitutional law is a required subject, not only on the bar exam but also on the civil service and diplomatic service examinations. In short, as a matter of theory, anyone who is going to be a teacher, a jurist, a civil servant, or a diplomat should have an accurate understanding of the Constitution. But this knowledge is useful only on the examination. Once one passes the examination and engages in a job, employers tell one, "Forget all you have studied at the university." In Japan, the Constitution is in most cases treated as important in principle, but of little importance in practice. This situation is typified by the fact that the majority of the Japanese people are opposed to amending Article 9 of the Constitution while they are in favor of the Self-Defense Forces. For them, the Constitution is a kind of ornament rather than an enforceable law.

\section{The Rule of Law and Due Process in Some Decisions of the Supreme Court of Japan}

The Supreme Court of Japan does not seem to consider it important to sustain the Rule of Law against governmental power. In the past forty or more years of history, there have been only five cases in which the Supreme Court has declared a statute unconstitutional. As there is no evidence that the Japanese legislature is particularly faithful to the Constitution, only five cases in forty years is too small a number. This fact proves that the Supreme Court

31. In this sense, Professor Parker is half right and half wrong when he says that the Japanese Constitution lacks authority. See Parker, The Authority of Law in the United States and in Japan, 33 OsAkA U.L. REv. 1, 13-15 (1986). 
of Japan has almost no idea that government action should be bound strictly by the Constitution. If the core of the Rule of Law is that governmental power be bound by law, and if the Rule of Law is to be realized through the judicial process, the scarcity of court decisions that have ruled statutes unconstitutional indicates that the Rule of Law is not realized in practice in Japan.

Moreover, these five decisions have had little impact on Japanese political and social life. Two decisions ruling malapportionment unconstitutional ${ }^{32}$ would have great impact on politics if the Supreme Court were to nullify the contested elections. But the Supreme Court did not invalidate the elections, and rendered the decisions ineffective. Even in the patricide case, ${ }^{33}$ which involved important problems of equal protection, the Supreme Court ruled the criminal code provision unconstitutional only on a technical ground. The other two cases in which the Supreme Court declared statutes unconstitutional were both concerned with economic liberty or property rights, ${ }^{34}$ and the constitutional issues in these cases had no significant meaning for public life. In short, the Supreme Court of Japan has never said nay to the government in a serious manner.

When looking at individual decisions, there are many that are doubtful from the point of view of the Rule of Law and due process. In the Nishiyama case,$^{35}$ the Supreme Court decided that the news-gathering activity at issue, whereby a reporter had taken advantage of a love affair to obtain a confidential telegram of the Ministry of Foreign Activity from a woman official, was illegal in light of the "spirit of [the] whole legal order." Of course, there is no law that prohibits a reporter from gathering news from his or her lover. This decision, which restricted freedom not by law but by such a vague concept as the spirit of the whole legal order, paid no attention at all to the Rule of Law or due process.

In a case in which the exclusion of illegally seized evidence was the key issue, the Supreme Court said that unlawful procedures of search and seizure alone would not exclude evidence because the value of material evidence for arriving at truth would be unchanged whether the procedure for securing it was lawful or not. To exclude evidence by reason of unlawful procedure is, according to the Supreme Court, an "improper way to investigate the truth of the case." 36 In spite of the detailed constitutional provisions requiring due

32. Kurokawa v. Chiba Prefecture Comm'n, 30 Minshū 223 (Sup. Ct., G.B., Apr. 14, 1976); Kanao v. Hiroshima Election Comm'n, 39 Minshū 1100 (Sup. Ct., G.B., July 17, 1985).

33. Aizawa v. Japan (The Patricide Case), 27 Keishū 265 (Sup. Ct., G.B., Apr. 4, 1973) (aff' $g 1$ Keisai Geppō 544 (Utsunomiya Dist. Ct., May 29, 1969) and rev'g 619 Hanrei Jihō 93 (Tokyo H. Ct., May 12, 1970)).

34. Hiraguchi v. Hiraguchi, 41 Minshũ 408 (Sup. Ct., G.B., Apr. 22, 1987) (ruling restrictions on partitions of co-owned forests unconstitutional); Umehara v. Japan (The Pharmacy Case), 29 Minshū 572 (Sup. Ct., G.B., Apr. 30, 1975) (ruling restrictions on the placement of pharmacies unconstitutional).

35. Nishiyama v. Japan, 32 Keishū 457 (Sup. Ct., 1st P.B., May 31, 1978)

36. 32 Keishū 1672 (Sup. Ct., 1st P.B., Sept. 7, 1978). 
process of law, the Supreme Court deemed the substantive truth more important than the procedure.

The idea of a strict distinction between "public law" and "private law," which has been a legal tradition in Japan since the Meiji era, is still strong. Although it is said in Japan that the Constitution stands on the AngloAmerican idea of the Rule of Law, the Administrative Case Procedure Law provides a special procedure peculiar to administrative cases. Thus, the Japanese legal system is constructed on the premise of a distinction between public law and private law, which does not quite correspond with the AngloAmerican Rule of Law. This is not wrong in itself, but if the distinction between public law and private law becomes a reason to reject the protection of people's rights, it results in the superiority of administration over the people.

A typical example of this is the Supreme Court decision in the Osaka airport case, ${ }^{37}$ in which the Supreme Court said that a suit to enjoin airplane landings and takeoffs at night was unlawful as civil litigation because it was nothing but a demand to change an operational decision of the aeronautic administrative power. The Supreme Court refused to consider the claims of the residents around the airport by saying that people could not lodge an objection against the administrative power through a civil procedure.

In the Hyakuri base case, ${ }^{38}$ a contract that the government made with a private party to acquire a base site for the Self-Defense Forces was alleged to be invalid because the Forces violated Article 9 of the Constitution. The Supreme Court declared that the Constitution does not limit government action done according to private law. According to the Court, because the Constitution is a public law and hence does not limit the actions of private parties, it does not limit government action when the government acts as a private party. Here, the formalistic distinction between public law and private law overrides the demand that all government action should be consistent with the Constitution.

\section{IV}

\section{Conclusion}

It is correct to say that the Rule of Law is a "universal principle of mankind" so long as the phrase refers to the protection of the rights and liberties of the people. The Constitution has adopted this principle. But as I have demonstrated, it is hard to say that in Japan these protections are fully realized in practice. There are various possible explanations. It is often pointed out that the Japanese people in general still regard law as the order of the ruling authority. Some suggest that the Japanese have no consciousness that the Constitution was established in order to bind governmental power by the people because the Constitution itself was given by a superior authority-

37. 35 Minshũ 1369 (Sup. Ct., G.B., Dec. 16, 1981).

38. 43 Minshū 385 (Sup. Ct., 3d P.B., June 20, 1989). 
the General Headquarters of the Supreme Commander for the Allied Powers. ${ }^{39}$ Further, the Japanese polity in practice has lacked an alternative to the ruling party. The Liberal Democratic Party ("LDP"), whose primary platform is the revision of the Constitution, has been in power since 1955. I think this fact must also be a reason that the supremacy of the Constitution over governmental power has been neglected in Japan. It is quite natural that the Supreme Court has never seriously attacked a government act, because all Supreme Court judges have been appointed by the LDP government. The realization of the Rule of Law in Japan cannot be expected without changing this political situation.

Of course, Marxists criticize the idea of the Rule of Law as no more than an ideology to disguise the rule of the bourgeoisie. Therefore, they say, to seek the realization of the Rule of Law is nonsense, or at best mere "reformism." 40 But the Rule of Law is a part of democracy-I would say, bourgeois democracy. And even if it were true that socialism is the ideal form of government, I do not think that socialism in a country that has never experienced bourgeois democracy can be real socialism at all.

However, it should be noted that the movement that seeks to realize the Constitution not only in principle but in practice is taking root among the Japanese people slowly but steadily. Many constitutional cases are links in this movement. Moreover, some present problems, such as the Recruit scandal ${ }^{41}$ and the excise tax, are bringing some kind of change in the political awareness of the people. These have the potential to alter Japanese politics radically. Perhaps the real Rule of Law and democracy will be brought to Japan in the future.

39. See generally N. Kobayashi, KenPō to Nihon-jin 188 (1987).

40. See M. Shimizu, Nihonkoku Kenpō no Iso 64-65 (1967); T. Sugimura, Ho no Shihai to Gyosei-Ho 79-88 (1970).

41. The Recruit scandal emerged in 1988. Japanese prosecutors contend that the information services and real estate corporate conglomerate Recruit Co. and a subsidiary bought influence in government by giving cash and discounted stock to top political figures in the ruling Liberal Demouratic Party and high ranking government bureaucrats. See Ex-Recruil Chief Questioned Over Objective in Share Deals, The Japan Times (Weekly Overseas Edition), Jan. 4, 1989, at 2. 